\title{
IMPLEMENTASI SAK EMKM (ENTITAS MIKRO, KECIL DAN MENENGAH) PADA UMKM BORNEO FOOD TRUCK SAMARINDA COMMUNITY
}

\author{
Ivana Nina Esterlin Barus \\ Andi Indrawaty \\ Danna Solihin \\ University of 17 Agustus 1945 Samarinda \\ Jl. Ir. H. Juanda No. 80, 75124, Indonesia \\ wiliva.couple@gmail.com
}

\begin{abstract}
At present the development of business world is increasingly rapid in Indonesia. However, the problem with EMKM is that there are not many EMKMs that are able to hold records, bookkeeping, and even financial reporting.Borneo Food Truck Samarinda Community have not been able to carry out and implement recording, bookkeeping, and financial reporting in their entities. The research objectives to be find out whether Borneo Food Truck Samarinda Community can implement this SAK EMKM in 2018 and to find out the obstacles faced in implementing the SAK EMKM in Borneo Food Truck Samarinda.

The research method used is qualitative research. Data collection techniques using interview techniques, documentation and observation. The result showed that of the thirty three UMKM Borneo Food Truck Samarinda Community respondents there were ten UMKM that made journals, inventory data, sales data and prepared financial reports and twenty three UMKM that did not make accounting records.
\end{abstract}

Keywords: Implementation, SAK EMKM, UMKM.

\section{PENDAHULUAN}

Kegiatan kewirausahaan yang dijalankan oleh EMKM (Entitas Mikro, Kecil, dan Menengah) dapat menciptakan lapangan pekerjaan bagi masyarakat. Namun, hal yang menjadi kendala EMKM adalah belum banyak EMKM yang mampu menyelenggarakan pencatatan, pembukuan bahkan pelaporan keuangan. Padahal penyelenggaraan pencatatan, pembukuan dan pelaporan keuangan adalah hal penting yang perlu dilakukan oleh setiap entitas, agar entitas dapat mengevaluasi kinerja entitas setiap tahunnya. Selain itu, entitas juga dapat menambah modal kerja usahanya dari pinjaman pihak perbankan dengan melampirkan laporan keuangan entitas.

Food truck adalah konsep penjualan makanan dengan menggunakan sebuah kendaraan (umumnya truk modifikasi) sebagai tempat usahanya. Pemesanan, makan, dan pelayanannya dilakukan di dalam kendaraan yang telah didesain sedemikian rupa untuk menarik para konsumen. Namun ternyata dibalik peluangnya menciptakan omset tinggi, 
food truck juga menyimpan risiko usaha yang tak kalah tingginya bahkan juga bisa berujung pada kebangkrutan usaha. Oleh karena itu dibutuhkan sebuah strategi agar perusahaan dapat menjalankan operasional perusahaan dengan baik dan strategi pemasaran yang harus selalu dikembangkan dan disesuaikan dengan kondisi pasar yang selalu berubah. UMKM Borneo Food Truck Samarinda Community sudah berdiri sejak tahun 2015 di kota Samarinda. UMKM Borneo Food Truck Samarinda Community menjual berbagai jenis makanan dan minuman yang banyak diminati oleh masyarakat. Namun, banyak pemilik UMKM Borneo Food Truck Samarinda Community yang belum mampu menyelenggarakan dan mengimplementasikan pencatatan, pembukuan dan pelaporan keuangan di entitas mereka.

Standar Akuntansi Keuangan untuk EMKM (Entitas Mikro, Kecil, dan Menengah) pada 18 Mei 2016 sudah diterbitkan oleh Dewan Standar Akuntansi Keuangan Ikatan Akuntan Indonesia dalam bentuk draft. Exposure Draft SAK EMKM (Standar Akuntansi Keuangan Entitas Mikro, Kecil, dan Menengah) berlaku efektif tanggal 1
Januari 2018. Penggunaan SAK EMKM ini merupakan hal yang paling terbaru diterapkan untuk seluruh entitas tanpa akuntabilitas publik. Oleh karena itu, peneliti tertarik melakukan penelitian yang berjudul "IMPLEMENTASI SAK EMKM (ENTITAS MIKRO KECIL DAN MENENGAH) PADA UMKM BORNEO FOOD TRUCK SAMARINDA COMMUNITY".

Dasar untuk membahas Implementasi SAK EMKM pada UMKM ini adalah Standar Akuntansi sebagai acuan penyusunan laporan keuangan untuk UMKM berbeda dengan standar akuntansi yang dipakai oleh sektor usaha non UMKM. Laporan keuangan adalah laporan yang berisi informasi keuangan sebuah organisasi. Laporan keuangan yang diterbitkan oleh perusahaan merupakan hasil proses akuntansi yang dimaksudkan sebagai sarana mengkomunikasikan informasi keuangan terutama kepada pihak eksternal. Menurut (Munawir, 2010) mendefinisikan laporan keuangan sebagai hasil dari proses akuntansi yang dapat digunakan untuk sebagai alat berkomunikasi antara data keuangan dan suatu aktifitas suatu perusahaan dengan pihak-pihak yang berkepentingan dengan data atau 
aktifitas perusahaan tersebut. Jenis Laporan Keuangan Lengkap Berdasarkan SAK EMKM:

Laporan posisi keuangan pada akhir periode (Laporan posisi keuangan entitas dapat mencakup akun-akun berikut kas dan setara kas, piutang, persediaan, aset tetap, utang usaha, utang bank, ekuitas). Laporan laba rugi selama periode (mencakup akun-akun sebagai berikut pendapatan, beban keuangan, beban pajak). Catatan atas laporan keuangan, yang berisi tambahan dan rincian akun-akun tertentu yang relevan diantaranya suatu pernyataan bahwa laporan keuangan telah disusun sesuai dengan ED SAK EMKM, ikhtisar kebijakan akuntansi, informasi tambahan dan rincian akun tertentu yang menjelaskan transaksi penting dan material sehingga bermanfaat bagi pengguna untuk memahami laporan keuangan.

Usaha Mikro, Kecil dan Menengah (UMKM)

\section{Usaha Mikro}

Kriteria usaha mikro menurut Undang-Undang No.20 Tahun 2008 tersebut adalah:

1. Memiliki kekayaan bersih paling banyak Rp50.000.000,00 (lima puluh juta rupiah) tidak termasuk tanah dan bangunan tempat usaha

2. Memiliki hasil penjualan tahunan paling banyak Rp300.000.000,00 (tiga ratus juta rupiah).

\section{Usaha Kecil}

Kriteria usaha kecil menurut Undang-Undang No.20 Tahun 2008 tersebut adalah:

1. Memiliki kekayaan bersih lebih dari Rp 50.000.000,00 (lima puluh juta rupiah) sampai dengan paling banyak Rp 500.000.000,00 (lima ratus juta rupiah) tidak termasuk tanah dan bagunan tempat usaha atau,

2. Memiliki hasil penjualan tahunan lebih dari Rp 300.000.000,00 (tiga ratus juta rupiah) sampai paling banyak Rp2.500.000.000,00 (dua milyar lima ratus juta rupiah).

\section{Usaha Menengah}

Kriteria usaha menengah menurut Undang-Undang No.20 Tahun 2008 tersebut adalah:

1. Memiliki kekayaan bersih lebih dari $\quad \mathrm{Rp} \quad 500.000 .000,00$ (lima ratus juta rupiah) sampai dengan paling banyak $\mathrm{Rp}$ 10.000.000.000,00 (sepuluh milyar rupiah) tidak termasuk 
tanah dan bagunan tempat usaha atau,

2. Memiliki hasil penjualan tahunan lebih dari $\mathrm{Rp}$ 2.500.000.000,00 (dua milyar lima ratus juta rupiah)

\section{METODE PENELITIAN}

Metode penelitian yang digunakan dalam penelitian ini adalah deskriptif kualitatif. Penelitian ini dilaksanakan pada UMKM Borneo Food Truck Samarinda Community yang bertempat di Samarinda, Kalimantan Timur. Teknik pengumpulan data yang digunakan dalam penelitian ini dengan cara memberikan kuisioner dan observasi lapangan. Sampel pada penelitian ini adalah food truck yang bergabung ke komunitas Borneo Food Truck, memiliki tempat reguler dan masih aktif dalam menjalankan bisnis ritel food truck serta 33 responden yang merupakan pemilik dari food truck dengan menggunakan teknik purposive sampling.

\section{HASIL DAN PEMBAHASAN}

Responden dalam penelitian ini terdiri dari 33 pelaku UMKM yang tergabung dalam komunitas Borneo Food Truck Samarinda, sebagian besar berlatar belakang pendidikan Sarjana sampai paling banyak $\mathrm{Rp}$ 50.000.000.000,00 (lima puluh milyar rupiah).

non ekonomi. Adapun jenis usaha yang dilaksanakan mayoritas dalam lingkup usaha manufaktur (industri makanan) dengan memperjakan karyawan sebanyak 2-4 orang per entitas. Aset dan penjualan rata-rata perusahaan berkisar $50-100$ juta per tahun dengan melalui sumber pendanaan (modal) sendiri. Sebagian besar pelaku UMKM tidak pernah mengajukan pinjaman/kredit ke bank.

Berdasarkan hasil penelitian, sebagian besar responden melakukan pecatatan keuangan sederhana sebatas pengetahuan pemilik perusahaan tanpa berdasarkan standar akuntansi keuangan. Pencatatan atas penjualan, pembelian dan pengeluaran diakukan dengan sederhana pada buku biasa dan tidak teratur, serta tidak lengkap. Hal ini dikarenakan minimnya pengatahuan pemilik mengenai penerapan standar akuntansi keuangan khususnya SAK EMKM dan tidak memperkerjakan karyawan khusus dalam hal menangani laporan keuangan perusahaan. Berikut komponen laporan keuangan 


$\begin{array}{lccc}\text { berdasarkan } & \text { SAK EMKM dan penelitian: } \\ \text { penerapannya } & \text { berdasarkan objek } & \end{array}$

Tabel 1.1 Hasil Penelitian Komponen SAK EMKM Penerapan Objek Penelitian

Aset Lancar

\section{Entitas mengklasifikasikan sebagai} asset lancar jika diperkirakan akan direalisasi atau dimiliki untuk dijual atau digunakan, dalam jangka waktu siklus operasi normal entitas, dimiliki untuk diperdagangkan, diharapkan akan direalisasikan dalam jangka waktu 12 bulan setelah akhir periode pelaporan; atau berupa kas atau setara kas, kecuali jika dibatasi penggunaannya dari pertukaran atau digunakan untuk menyelesaikan liabilitas setidaknya 12 bulan setelah akhir periode pelaporan

\begin{tabular}{|c|c|c|}
\hline & $\begin{array}{l}\text { dimiliki untuk diperdagangkan, } \\
\text { diharapkan akan direalisasikan } \\
\text { dalam jangka waktu } 12 \text { bulan setelah } \\
\text { akhir periode pelaporan; atau berupa } \\
\text { kas atau setara kas, kecuali jika } \\
\text { dibatasi penggunaannya dari } \\
\text { pertukaran atau digunakan untuk } \\
\text { menyelesaikan liabilitas setidaknya } \\
12 \text { bulan setelah akhir periode } \\
\text { pelaporan }\end{array}$ & \\
\hline Aset Tidak Lancar & $\begin{array}{l}\text { Entitas mengklasifikasikan semua } \\
\text { aset lainnya sebagai tidak lancer, } \\
\text { jika siklus operasi normal entitas } \\
\text { tidak dapat diidentifikasi dengan } \\
\text { jelas, maka siklus operasi } \\
\text { diasumsikan } 12 \text { bulan. Aset tetap } \\
\text { dicatat sebesar biaya perolehannya } \\
\text { jika aset tersebut dimiliki secara } \\
\text { hukum oleh entitas. Aset tetap } \\
\text { disusutkan menggunakan metode } \\
\text { garis lurus tanpa nilai residu }\end{array}$ & $\begin{array}{l}\text { Aset tidak lancar meliputi } \\
\text { peralatan dan kendaraan. }\end{array}$ \\
\hline $\begin{array}{l}\text { Liabilitas Jangka } \\
\text { Pendek }\end{array}$ & $\begin{array}{l}\text { Entitas mengklasifikasikan liabilitas } \\
\text { sebagai liabilitas jangka pendek jika } \\
\text { diperkirakan akan diselesaikan } \\
\text { dalam jangka waktu siklus normal } \\
\text { operasi entitas, dimiliki untuk } \\
\text { diperdagangkan; kewajiban akan } \\
\text { diselesaikan dalam jangka waktu } 12 \\
\text { bulan setelah akhir periode } \\
\text { pelaporan, atau entitas tidak } \\
\text { memiliki hak tanpa syarat untuk }\end{array}$ & $\begin{array}{l}\text { Liabilitas yang dimiliki } \\
\text { oleh entitas adalah utang } \\
\text { dagang }\end{array}$ \\
\hline
\end{tabular}

Aset lancar meliputi kas, piutang, persediaan dan perlengkapan. 


\begin{tabular}{|c|c|c|}
\hline & $\begin{array}{l}\text { menunda penyelesaian liabilitas } \\
\text { setidaknya } 12 \text { bulan setelah akhir } \\
\text { periode pelaporan. }\end{array}$ & \\
\hline Ekuitas & $\begin{array}{l}\text { Modal yang disetor oleh pemilik } \\
\text { dana dapat berupa kas atau setara } \\
\text { kas atau aset nonkas yang dicatat } \\
\text { sesuai dengan peraturan } \\
\text { perundangan yang berlaku }\end{array}$ & $\begin{array}{l}\text { Modal entitas merupakan } \\
\text { modal investasi pemilik } \\
\text { berupa kas dan aset non } \\
\text { kas meliputi peralatan dan } \\
\text { kendaraan }\end{array}$ \\
\hline $\begin{array}{l}\text { Pendapatan dan } \\
\text { Beban }\end{array}$ & $\begin{array}{l}\text { Pendapatan penjualan diakui ketika } \\
\text { tagihan diterbitkan atau pengiriman } \\
\text { dilakukan kepada pelanggan. Beban } \\
\text { diakui saat terjadi. }\end{array}$ & $\begin{array}{l}\text { Pendapatan yang diperoleh } \\
\text { berupa penjualan produk. } \\
\text { Biaya yang dikeluarkan } \\
\text { berupa biaya produksi, } \\
\text { biaya transportasi, biaya } \\
\text { kebersihan dan keamanan. }\end{array}$ \\
\hline
\end{tabular}

Sumber: data diolah

\section{KESIMPULAN}

Berdasarkan observasi terhadap 33 UMKM "Borneo Food Truck Samarinda Community" terdapat 10 UMKM yang membuat jurnal, data persediaan, data penjualan dan menyusun laporan keuangan, yaitu: UMKM (Arbainah, Rafa Food Truck, Kedai Incos Putri, Tisna Taco, Warling, Mister Blek, Surga Bubur, Bu Sri Geprek, Raja Pisjo dan Indomaret) dan 23 UMKM yang tidak melakukan pencatatan.

Sepuluh UMKM yang menyelenggarakan catatan akuntansi tersebut, terdapat 2 UMKM yang menyelenggarakan catatan akuntansi secara manual yaitu UMKM (Arbainah dan Rafa Food Truck). Selebihnya, terdapat 8 UMKM yang telah memakai software akuntansi dalam melakukan pencatatan akuntansi.

Kendala yang dihadapi oleh UMKM dalam penyusunan laporan keuangan adalah kurangnya pengetahuan mengenai standar akuntansi dalam penyusunan laporan keuangan dan sumber daya manusia yang tidak berlatar belakang pendidikan akuntansi yang menyelenggarakan pencatatan akuntansi UMKM mengakibatkan pencatatan akuntansi dibuat secara sederhana. Selain itu, fokus pelaku usaha UMKM hanya kepada peningkatan penjualan dan belum terfokus untuk menyelenggarakan pencatatan yang lebih akurat sesuai standar akuntansi EMKM. 
SARAN

Pelaku usaha UMKM dapat menerapkan SAK EMKM dalam pencatatan dan pelaporan keuangan agar dapat mengetahui secara jelas kinerja keuangan UMKM secara jelas dan tidak dikaitkan dengan kekayaan pribadi pemilik usaha. Pencatatan keuangan dan pelaporan keuangan yang sudah memakai standar SAK EMKM dapat digunakan apabila pemilik usaha mengajukan permohonan kredit ke Perbankan, sehingga pihak perbankan dapat dengan jelas menilai kinerja keuangan UMKM.

\section{DAFTAR PUSTAKA}

Anonim. 2018. Standar Akuntansi Keuangan EMKM.

Depkop. 2017. www.depkop.go.id. [Online] Available at: www.depkop.go.id/pdfviewer/?p=uploads/tx_rtgfiles/san dingan_data_umkm_20122013.pdf

[Diakses Rabu Juni 2017].

Fatwa. 2016. Analisis Penerapan SAK ETAP Pada Usaha Kecil Menengah (UKM) Penggilingan Padi. Jurnal Kajian Ilmiah Akuntansi, 5 (Fakultas Ekonomi UNTAN (KIAFE)).

Harahap, S. S., 2011. Teori Akuntansi. Revisi 2011 penyunt. Rajawali Pers: Jakarta.
IAI, D. 2009. Standar Akuntansi Keuangan. Jakarta: Salemba Empat.

IAI, D. 2016. Exposure Draft Standar Akuntansi Keuangan Entitas Mikro, Kecil dan Menengah. Dewan Standar Akuntansi Keuangan Ikatan Akuntan Indonesia: Jakarta.

Indriantoro, B. S. d. N. 2010. Metodologi Penelitian Bisnis untuk Akuntansi dan Manajemen. Yogyakarta: BPFE Yogyakarta.

Kemenkumham. 2008. Undang-Undang No. 20 Tahun 2008 Tentang Usaha Mikro, Kecil dan Menengah. s.1.:s.n.

Lutfiaazahra, A., 2015. Implementasi Satandar Akuntansi Keuangan Entitas Tanpa Akuntabilitas Publik (SAK ETAP) Pada UMKM Pengrajin Batik di Kampoeng Batik Laweyan Surakarta. Surakarta, Fakultas Keguruan dan Ilmu Pendidikan Universitas Sebelas Maret Surakarta, pp. 1133.

Munawir, 2010. Analisa Laporan Keuangan. keempat penyunt. Liberty: Yogyakarta.

Norkamsiah, A. S. d. A. I. K., 2016. Penerapan Standar Akuntansi Keuangan Entitas Tanpa Akuntabilitas Publik (SAK ETAP) Pada Penyusunan Laporan Keuangan. Jurnal Ekonomi dan Keuangan, Volume 13.

Sadeli, L., 2008. Dasar-Dasar Akuntansi. PT. Bumi Aksara: Jakarta. 
Sugiyono, 2013. Metode Penelitian Bisnis. CV. Alfabeta: Bandun.

Umar, H., 2013. Metode Penelitian Untuk Skripsi dan Tesis Bisnis.
Raja Grafindo Persada: Jakarta.

Warren, C. J. M. R. d. P. E. F., 2014. Accounting Indonesia Adaptation. Salemba Empat: Jakarta.

Penelitian ini didanai oleh Direktorat Jenderal Penguatan Riset dan

Pengembangan Kementerian Riset, Teknologi dan Pendidikan Tinggi dengan nomor kontrak 509/KONTRAK-PENELITIAN/K11/KM/2018 Tgl 22 Februari 